慶應義塾大学学術情報リポジトリ

Keio Associated Repository of Academic resouces

\begin{tabular}{|c|c|}
\hline Title & $\begin{array}{l}\text { Structure-activity relationships of nitrosamines and nitramines which stimulate UDP- } \\
\text { glucuronosyltransferase activities in vitro }\end{array}$ \\
\hline \multicolumn{2}{|l|}{ Sub Title } \\
\hline Author & $\begin{array}{l}\text { 松井，道夫(Matsui, Michio) } \\
\text { 永井，総子( Nagai, Fusako) } \\
\text { 鈴木，恵真子( Suzuki, Emako) } \\
\text { 岡田，正志( Okada, Masashi) }\end{array}$ \\
\hline Publisher & 共立薬科大学 \\
\hline Publication year & 1984 \\
\hline Jtitle & $\begin{array}{l}\text { 共立薬科大学研究年報 (The annual report of the Kyoritsu College of } \\
\text { Pharmacy). No.29 (1984. ) , p.29- } 30\end{array}$ \\
\hline \multicolumn{2}{|l|}{ JaLC DOI } \\
\hline \multicolumn{2}{|l|}{ Abstract } \\
\hline Notes & 抄録 \\
\hline Genre & Technical Report \\
\hline URL & $\begin{array}{l}\text { https://koara.lib.keio.ac.jp/xoonips/modules/xoonips/detail.php?koara_id=AN00062898-0000002 } \\
\text { 9-0029 }\end{array}$ \\
\hline
\end{tabular}

慶應義塾大学学術情報リポジトリ(KOARA)に掲載されているコンテンツの著作権は、それぞれの著作者、学会または出版社/発行者に帰属し、その権利は著作権法によって 保護されています。引用にあたっては、著作権法を遵守してご利用ください。

The copyrights of content available on the KeiO Associated Repository of Academic resources (KOARA) belong to the respective authors, academic societies, or publishers/issuers, and these rights are protected by the Japanese Copyright Act. When quoting the content, please follow the Japanese copyright act. 
No. 29 (1984)

\title{
Structure-activity Relationships of Nitrosamines and Nitramines which Stimulate UDP-Glucuronosyltransferase \\ Activities in vitro*
}

\author{
Michio Matsui, Fusako Nagai, Emako Suzuki ${ }^{* *}$ and Masashi OKadA** \\ 松井道夫, 永井総子, 鈴木恵真子**, 岡田正志**
}

Conjugation of endogenous and exogenous compounds with glucuronic acid is catalyzed by hepatic microsomal UDP-glucuronosyltransferase. This enzyme is latent in freshly prepared microsomes and can be activated by physical, chemical or enzymatic perturbation of the microsomal membrane. The hereditary deficiency of UDP-glucuronosyltransferase activity toward bilirubin and several substrates is well known in Gunn rats, a mutant strain of Wistar rats. When $N, N$-diethylnitrosamine is added to Gunn rat liver enzymes, the deficiency in transferase activity toward 2-aminophenol disappears and in addition, its activity in preparations from both Gunn and Wistar rats is stimulated to equally high levels. $\quad N, N$-Diethylnitrosamine was subsequently found to increase the transferase activities toward certain substrates such as paracetamol, 2-aminobenzoic acid, 4-nitrophenol, and 4-methylumbelliferone. However, this nitrosamine does not stimulate the activities toward menthol, phenolphthalein, and bilirubin. Since the discovery of the carcinogenicity of $\mathrm{N}, \mathrm{N}$-dimethylnitrosamine in the rat, a large number of nitrosamines have been synthesized and found to be carcinogenic in various experimental animals. Though activation of UDP-glucuronosyltransferase toward 2-aminophenol and 4-nitrophenol has been studied extensively, the potential of other nitrosamines as activators of the transferase has not been reported. Recently alkyl ketones such as butan-2-one and pentan-2-one were shown to activate the transferase toward 2-aminophenol in a manner similar to $\mathrm{N}, \mathrm{N}$-diethylnitrosamine. Another example of genetic deficiency of UDPglucuronosyltransferase activity was reported recently, and its deficient activity toward androsterone was not reversed by addition of $N, N$-diethylnitrosamine and pentan-2-one. To extend the structure-activity relationships of in vitro activators, we examined twelve nitrosamines and seven nitramines for the ability to modify UDP-glucuronosyltransferase activities toward 2-aminophenol, 4-nitrophenol, phenolphthalein, and androsterone. Nitramines, in which the $N$-nitroso group of nitrosamines is substituted for the $N$-nitro group, are in general, less toxic and more stable than nitrosamines and seem to have structural characteristics similar to nitrosamines. $N$-Monosubstituted nitrosamines are very unstable and readily undergo spontaneuos decomposition, while the corresponding

* 本報告は Biochem. Pharmacol., 33, 2647-2651（1984）に発表.

** 東京生化学研究所 
No. 29 (1984)

nitramines are comparatively stable. Therefore, nitramines could be suitable compounds for elucidation of structure-activity relationships of the activators.

From studies of modification of the transferase activities by nitrosamines and nitramines, it was apparent that the nitramines modified the transferase activities in a manner similar to nitrosamines, and that the compounds with an $N, N$-diethyl structure exhibit maximum activation toward 2-aminophenol and 4-nitrophenol. Stimulation of the activity toward 4-nitrophenol was not as great as that toward 2-aminophenol. Cooperative activation of the transferase by the combined addition of UDP- $N$-acetylglucosamine or Triton $\mathrm{X}-100$ suggests that the activation mechanisms of $N, N$-diethylnitrosamine and $N, N$-diethylnitramine differ from those of UDP- $N$-acetylglucosamine and Triton X-100. The maximum transferase activities toward 2-aminophenol and 4-nitrophenol were obtained by the combined addition of $N, N$-diethylnitramine and Triton $\mathrm{X}-100$. The $N, N$-diethyl-substituted nitrosamine and nitramine highly stimulated the transferase activity, and this stimulation was found only with certain substrates. Elongation of the alkyl chains or introduction of carboxy, hydroxy, or oxo groups into the alkyl chains did not result in stimulatory ability. This suggests precise structural requirements for optimal activation of a specific transferase. In fact, some of the nitrosamines and nitramines may interact in the wrong way with the enzyme molecule and inhibit the activity. Inhibition of activity by several nitrosamines and nitramines was pronounced when 2-aminophenol and androsterone were used as substrats. The activity of the transferase is divided roughly into two groups either on the basis of latefoetal and neonatal development of the activity or on the basis of the inducibility by 3-methylcholanthrene $\left(\mathrm{GT}_{1}\right)$ and phenobarbital $\left(\mathrm{GT}_{2}\right)$. There is a remarkable similarity between late-foetal and $\mathrm{GT}_{1}$ substrates and between neonatal and $\mathrm{GT}_{2}$ substrates. Moreover, some of the late-foetal and $\mathrm{GT}_{1}$ clusters are activated by $N, N$-diethylnitrosamine and $N, N$-diethylnitramine. These functional heterogeneities of the transferase may be a reflection of sequential or conformational heterogeneities of the enzymes. However, further study is required to obtain insight into the stimulatory mechanism of UDP-glucuronosyltransferase activity. 